\title{
La iconografía religiosa en el siglo XVIII *
}

\section{LA ICONOGRAFIA COMO FUENTE DE ESTUDIO}

La imagen que tenemos de muchos santos, vírgenes y cristos es la que nos han ofrecido las artes cultas, nuestra retina retiene la imagen de una Santa Casilda cortesana pintada por Zurbarán; sin embargo, esta santa es mejor reconocida por los que han visitado su santuario como una mujer tumbada. Con esto quiero decir que el arte o los artistas crean y recrean imágenes un poco aleatorias o anecdóticas, produciendo confusiones de tipo iconográfico en algunos casos.

Uno de los problemas que hay que apuntar es el hecho de que hoy conocemos el arte religioso que está en los museos, especialmente de Bellas Artes, y éstos sólo guardan una parte de las imágenes del pasado. Hasta hace poco no se ha comenzado a exhibir y estudiar ese otro tipo de arte llamado popular y que está representado por estampas, exvotos, capillitas, medallas, escapularios, relicarios, velas y un sinfín de elementos que se guardan más bien en los museos etnográficos o de artes y tradiciones populares. Todos estos objetos, que de hecho han sido utilizados más comúnmente, nos pueden servir como fuentes inagotables para el conocimiento de la iconografía y la historia de nuestro pasado. Abundantes monografías hay sobre los pintores del Barroco español; en cambio, ¿cuántas sobre estampas religiosas del mismo período histórico, o de otras épocas? Habiendo una gran cantidad de material de este «arte popular» es extraño que contemos con pocos estudios. La investigación bebe una y otra vez de las mismas fuentes. ¿Por qué los libros de iconografía de santos nos muestran casi siempre imágenes de grandes cuadros, relicarios ostentosos, estatuas de autores archiconocidos, y no nos presentan series de estampas en las que se vea la evolución iconográfica de una figura sagrada?

Este artículo forma parte de un trabajo de investigación más amplio titulado «La religiosidad popular en tiempos de Carlos IIl», que ganó el accesit del premio extraordinario "Marqués de Lozoya» del Ministerio de Cultura con motivo de la conmemoración de Carlos III y la Ilustración. El trabajo refleja la devoción popular en la España del siglo XVIII a través de doce santuarios representativos. Las fotografías correspondientes al Museo del Pueblo Español han sido realizadas por D. José Luis Municio García. 
En el estudio de la platería, que podría ser diferente, ocurre lo mismo, se miman las grandes obras: preciosos relicarios, copones, custodias, portapaces, ricas joyas, etc. Pero no interesan las medallas devocionales, las cruces que se llevan colgadas al cuello, los relicarios que portaban las mozas ensartados en enormes collares. ¿Y cómo no interesa el estudio de esos pequeños recuerdos?, objetos que han tenido un valor tradicional excepcional, pues las personas se confiaban en ellos como en preciosos talismanes, objetos que han reportado a iglesias y monasterios un intercambio económico y espiritual importantísimo. Tenemos que tener en cuenta que los grandes santuarios, al extender su culto y pedir ayuda económica por los pueblos a los devotos, entregaban, a cambio de unas monedas, medallas, estampas, crucifijos, etc. que se guardaban como reliquias de gran valor. Los peregrinos, los que cumplían promesas visitando un santuario, llevaban a sus casas parte del misterio de la gracia que rodeaba una imagen o una reliquia de su devoción, concentrado o depositado en ese pequeño objeto que podían llevar sobre su cuerpo, colgar en la pared de su casa o en la cabecera de su cama. Es decir, las gentes han tenido conocimiento de tal Virgen, de tal santo, no por los cuadros de pintores famosos, sino por elementos más cercanos a su vida $y$, principalmente, más asequibles.

La Iglesia se ha preocupado mucho por ser la difusora de estas imágenes, por conservar durante siglos el privilegio de hacerlas o, en todo caso, dar el permiso de fabricarlas y venderlas. Por medio de estampas y medallas han difundido el conocimiento de su santuario, el poder de la imagen y sus formas inconfundibles. El estudio de estas imágenes, sus artífices, sus clientes, sus vías de difusión, los gustos, las modas, el comercio y el poder que hay alrededor de ellas es un campo vastísimo.

Ciertos historiadores franceses que se dedican al estudio de las mentalidades han tomado la iconografía como fuente de sus trabajos históricos. Michel Vovelle, uno de los representantes de este interés por una nueva perspectiva histórica, sitúa en la década de los sesenta el giro esencial que coloca a la iconografía en el rango de las técnicas sobre las que se apoya la historia de las mentalidades ${ }^{1}$. Precisamente son los historiadores de la cultura popular los que necesitan de estas fuentes iconográficas, tal vez por carecer de otras y tener en este campo un abundante material. No obstante, el estudio de series anónimas de objetos promueve la necesidad de nuevas técnicas y de planteamientos metodológicos específicos que están por probar. Pero ya se han comenzado a estudiar retablos, exvotos, monumentos funerarios, imaginería popular, desentrañando con ellos siglos de desconocimiento.

' Michel Vovelle, Ideologias y mentalidades (Barcelona, 1985), p. 53. 


\section{CAMBIOS ICONOGRÁFICOS}

La imágenes religiosas parecen objetos tan estáticos, tan inamovibles en el tiempo que, cuando los vemos y reconocemos sus símbolos y atributos, dan la sensación de que siempre han sido iguales. Pero esto no es cierto, la estética, el gusto y la mentalidad han cambiado sus formas y sus usos. Las antiguas imágenes medievales, majestuosas y sencillas, no gustaban en los siglos XVII y XVIII; parece que por entonces se intensificó la costumbre de vestirlas.

Las imágenes de vírgenes sentadas con el niño en el regazo, al ser vestidas y aparentar estar en pie, pierden naturalidad en sus manos; por eso, en muchos casos, fueron cortadas para cumplir mejor el nuevo papel. Es durante el siglo XVIII, especialmente en su segunda mitad, cuando las imágenes marianas españolas tendieron a ser alteradas para dar un aspecto uniforme y majestuoso. En cierta medida, hemos heredado este gusto por imágenes embutidas en ropajes campaniformes, joyas o bordados, con larga melena y una corona enorme.

Los cristos igualmente son vestidos, aunque sin tanto adorno, con enaguas de lino, faldones de colores y ornamentos diversos, colocándoles largas pelucas encima de la talla original.

Las alteraciones en la vestimenta, adorno y tocado están en relación con la moda y el gusto temporal, pero también con la visión de lo sagrado que tiene la gente. Los cambios tardan mucho en imponerse, sobre todo en imágenes antiguas. Las nuevas que se realizan pueden llevar el toque de la época, pero las antiguas presentan problemas porque se intentan adaptar a las nuevas necesidades. El siglo XVIII creo que deja una fuerte impronta en el gusto de cómo deben ser las imágenes, que ha llegado hasta nosotros.

Los santos, en cambio, han variado menos su aspecto a lo largo del tiempo. Para su representación se han elegido momentos estelares de sus vidas, y los atributos que les son propios $y$, tal vez, la elección de un tema en una época determinada, sea lo que caracterice las diferentes etapas iconográficas.

Para datar y reconocer la época en que está hecha una estampa o una medalla, si no tiene fecha - cosa frecuente en las medallas-, hemos de guiarnos por datos o detalles aparentemente insignificantes, como ciertos aditamentos que se colocan en las imágenes y que se reflejan en las pequeñas estampas y medallas. De todas formas, es esencial conocer al detalle cómo eran los altares donde se daba culto a reliquias e imágenes, sus adornos, pinturas y esculturas, especialmente la imagen principal, centro 
de todas las miradas y los rezos; éstas serán el modelo para todas las demás reproducciones que se hagan.

Los cambios iconográficos que presentan ciertas imágenes pueden ser: estructurales, como el paso de yacente o sedente a erguido, o puntuales por adición de elementos de carácter simbólico o decorativo, producto generalmente de ofrendas de gente devota.

\section{ICONOGRAFIA DE CRISTO}

Las imágenes de Cristo elegidas para este estudio están relacionadas con la Pasión; se trata de un Crucifijo y un Jesús Nazareno.

De Cristo se han venerado tanto sus reliquias como sus imágenes; el culto a sus reliquias se promovió con las Cruzadas y la traída desde Tierra Santa de trozos de la cruz, otros de la corona de espinas, de su sangre, etc. Las primeras imágenes de Cristo que recibieron culto fueron los crucifijos o «majestad» en el medievo, pero la Pasión en todas sus facetas fue puesta en imágenes en los siglos XV, XVI y XVII. En el XVIII encontramos una superposición de todas estas devociones, aunque todavía con un interés especial por la Pasión.

¿Qué es lo que se destaca de las imágenes más veneradas de Cristo en el siglo XVIII? Probablemente su realismo, el que parezca como de carne, que se dice del Cristo de Burgos.

\section{Descripción del Cristo de Burgos en el siglo XVIII}

Cap. XI. 79. Es tan admirable su arquitectura, y su contextura tan rara, que toda es naturalmente tratable, y flexible; de suerte, que cede fácilmente, en qualquiera parte, que le apliquen el dedo, como si fuera de carne. La sagrada cabeza la tiene inclinada al lado derecho, y se dexa mover con facilidad al lado contrario, y sobre el pecho ${ }^{2}$.

Este fragmento forma parte de una larga descripción del Cristo. Resumiremos en primer lugar cómo se le describe arquetípicamente y, en segundo lugar, cuáles son sus características propias. El arquetipo de este Cristo es el siguiente:

- flexible;

2 P. Lovinno, Historia y milagros del Santísimo Christo de Burgos con su novena (Madrid, 1740), p. 59. 
- representativo del divino original, no se le puede mirar de cerca;

- imita al natural;

- está incorrupto;

- hombre perfecto.

Características propias: un Cristo clavado en la cruz con la cabeza inclinada al lado derecho; cabello, barba y uñas muy naturales; nervios, arterias $\mathrm{y}$ huesos se perciben; llagas y heridas con sangre medio cayendo; a los pies unos huevos de avestruz y enagüillas o pañetes interiores de lino. Estos rasgos tan singulares son los que identifican al Cristo de Burgos, siendo los que se plasman en sus reproducciones, como veremos más adelante.

Hay tres elementos ajenos a la escultura propiamente dicha que son muy representativos de este Cristo y que tanto hoy como en el siglo XVIII eran los signos de reconocimiento:

- Un largo faldellín que antiguamente era de lino blanco y que hoy en día es de terciopelo, cambiando sus colores con los ciclos litúrgicos.

- Unos huevos de avestruz, ofrenda no rara en el medievo, época en que se tenían como símbolo de la Resurrección de Cristo ${ }^{3}$. En el siglo XVIII se creía, erróneamente, que estaban a sus pies para ocultar la falta de algunos dedos.

- Una corona de espinas de oro a sus pies, ofrenda de D. Pedro Girón, maestre de Calatrava, que recibió una gran herida en la cabeza.

Un problema iconográfico se nos presenta con el Cristo de Burgos al existir dos imágenes similares ${ }^{4}$, ambas con largo faldellín, huevos de avestruz y cabeza inclinada sobre el hombro derecho. En las estampas este problema se resuelve, pues se indica a qué convento pertenece la imagen representada, pero en los pequeños crucifijos de plata la distinción es prácticamente imposible.

El Cristo de Medinaceli es una escultura realizada en un taller sevillano durante la primera mitad del siglo XVII. Representa un Nazareno modelado anatómicamente, especialmente las partes que van a quedar expuestas a la veneración (cabeza, manos y pies):

3 G. LLOMPART, «Cabos sueltos de folklore religioso mallorquín», RDTP, XXIV (1968), pp. 45-48. Un pequeño pero interesante estudio sobre el simbolismo de los huevos de Pascua y las ofrendas de huevos.

4 En el siglo xviII hay una pugna entre los trinitarios y agustinos de Burgos en la que se dirime a cuál de las órdenes corresponde el llamado Cristo de Burgos. La imagen que hoy admiramos en la catedral, y que es objeto de nuestro estudio, era la que perteneció al convento de los agustinos en donde estuvo hasta la exclaustración. 
Los cabellos al natural; el rostro sereno y dolorido; la boca entreabierta; la barbilla corta. Los brazos están articulados por los hombros para facilitar el ser vestido; un leve sudario, de líneas simples, cubre las caderas... ${ }^{\text {s. }}$.

Un dato importante es el ser una imagen para vestir, así que se le reconoce por su túnica morada bordada en oro, sus manos atadas delante, una sobre la otra, el escapulario trinitario, la larga melena postiza y la corona de espinas.

$\mathrm{Su}$ túnica, que en la actualidad es de terciopelo morado, en el siglo XVIII era de tafetán también morado, pero aparentaba ser menos bordada que ahora lo está, según se contempla en las estampas. El escapulario trinitario es un objeto que les era impuesto a los cautivos rescatados y, por semejanza, como la imagen también fue cautiva y rescatada, se le colocó esta insignia a su llegada a Madrid. La corona de espinas y el pelo largo natural se presentan ya en estampas de 1724; parece ser que la melena le viene desde los primeros años de estancia en Madrid. Así se describe al Cristo en el siglo XVIII:

Una imagen devotísima de Jesús Nazareno, de estatura natural, con su tunicela de tafetán morado, ligadas manos, y cuello con un grueso cordón, texido de seda y oro... ${ }^{6}$.

\section{ICONOGRAFÍA DE MARÍA}

La iconografía mariana española, tan rica en variedades, no ha sido objeto de estudios compendiadores y generales, exceptuando la obra de Manuel Trens ', que trata de llenar ese vacío analizando las imágenes de María, partiendo de los primeros siglos del cristianismo hasta nuestros días. Vamos a seguir sus clasificaciones iconográficas $y$, por ello, las dividimos en orantes y entronizadas, considerándolas categorías conceptuales más que formales.

\section{Virgenes orantes}

Consideramos a Ntra. Sra. de las Angustias como Virgen contemplativa dolorosa, porque tiene a su Hijo muerto en el regazo y lo mira en actitud

5 D. Fernández Villa, Historia del Cristo de Medinaceli (Madrid, 1982), p. 4.

6 Melchor Del EspfRitu SANTO, El diamante trinitario (Madrid, 1713), p. 442.

7 M. María Trens, Iconografía de la Virgen en el arte español (Madrid, 1946). 
compasiva y de dolor. Las Angustias de Granada es lo que comúnmente llamamos una Piedad, tema iconográfico de origen alemán que surge hacia los siglos XIII-XIV. Esta Virgen de Granada parece ser que sufrió diversas transformaciones, ya que en su origen era una Dolorosa a la que se añadió el Cristo muerto y la cruz en los siglos XVII-XVIII.

Dixe ya el motivo de vestir a nuestra madre soberana con el traje que oy se observa: en cuyos principios de el, se significaban las manos de esta Señora unidas sobre el pecho; pero con la ofrenda que hizo el prelado de el rico pectoral de corpulento tamaño, pareció competente cerrar por el pecho la rizada túnica blanca, colocando en él esta preciosa alhaja, y separar manos y brazos, demostrándolos en acción más expresiva. Asi se executó, concurriendo a la disposición de este aderezo el eminente escultor, ya mencionado, D. Pedro Cornejo, que con la sabia pericia de su acierto, proporcionó la acción con bello decoro, muy a satisfacción de los interesados, por los años de 1718. Dando comodidad para ello la situación de las manos ocultas, por estar comprimidas en el pecho, tendidas una sobre otra; y como en la pintura y escultura sólo se atiende a la representación exterior del trasunto sensible, para conmover el espíritu a la contemplación del objeto celestial, no se halla reparo en practicar lo expresado ${ }^{8}$.

Parece que el Cristo muerto y la insignia de la cruz se pusieron a esta imagen dolorosa para que fuera igual a la pintura en tabla de las Angustias que regaló o trajo Isabel la Católica a Granada; de esta forma la imagen podía sustituir en el altar a la famosa tabla. Más tarde, al quedar extraña la escultura con las manos sobre el pecho, se le hizo una reparación para que tuviera las manos extendidas y, finalmente, se decidió ponerle el traje al estilo de las dolorosas españolas de túnica blanca y manto negro, según la costumbre que había de vestir las imágenes al gusto de los reyes.

La Virgen de los Desamparados es un ejemplo de imagen activa protectora, amparadora de los inocentes que tiene en su falda. Pero esta imagen de María ha pasado por muchas vicisitudes desde que se hiciera para su cofradía poco después de 1416.

La forma que tenía esta escultura era poco común para una imagen de María, pues era yacente. Esta expresión estaba motivada por el uso que se hacía de la escultura; se la llevaba reposada sobre el féretro de los ajusticiados y de los cofrades muertos con un almohadón bajo la cabeza; de ahí que su barbilla casi pegue con el cuerpo y que su dorso sea plano. Cuando esta práctica cayó en desuso con el tiempo, se la comenzó a colocar inhiesta

8 D. SÁnchez SaRAvia, Compendio bistórico del origen y culto en Granada de Nira. Sra. de las Angustias (Granada, 1777), p. 29. 
en su capilla, necesitando de muchos retoques y cambios para disimular su antigua forma.

Para disimular su torso liso se le puso un manto y para levantar sus manos yacentes se fabricó un armazón que obligó a ocultar completamente la escultura:

Hasta mediados del siglo XVII ostentó la venerada escultura el capillo, que fue sustituido por la cabellera larga y rizada, sujeta por la corona y rostrillos de pedrería. Pero la modificación más importante fue la que se hizo para elevar la mano derecha de la imagen. Su posición indicaba claramente su origen de escultura yacente. Para sostener la nueva mano, más elevada, se hizo un antiestético armazón que obligó a ocultar totalmente el delantero de la imagen ${ }^{9}$.

Durante el siglo XVI y XVII la imagen no se mostraba vestida, sino simplemente adornada con joyas. En cambio, había varios y ricos doseles para llevarla en procesión. De finales del XVII y plenamente del XVIII es la costumbre de vestirla; por la relación de alhajas de 1767 sabemos que la Virgen tenía entonces 20 riquísimos mantos; en cambio, un siglo después tenía sólo tres mantos buenos.

Podemos deducir que a partir del siglo XVIII se le comenzaron a hacer los cambios más importantes, al decidirse en 1701 dejar a la imagen en su nicho y no volverla a sacar y hacer otra para las procesiones y rogativas. La necesidad de colocarla en el altar permanentemente provocó todos estos cambios que vamos a relatar en forma de compendio:

[...] hasta que fue revestida y devuelta a su Real Capilla pudimos apreciar, no sin algún esfuerzo, que el cuerpo total de la imagen desvestida ( el armazón o jaula troncocónica, que lo sostiene acampanándolo) está compuesto de dos elementos, hoy soldados o ensamblados, e incluso disimulada su unión por aditamentos plásticos, pero distinguibles al detenido análisis: uno delantero principal, la propia figura; otro adjetivo y posterior, añadido luego unificado plenamente en la estofa y el decorado ${ }^{10}$.

Las vicisitudes por las que pasa la imagen de Nuestra Señora de los Inocentes y Desamparados, pueden resultar modélicas y aleccionadoras de los enormes cambios que sufrieron una gran cantidad de imágenes antiguas.

9 E. APARicio Olmos, La imagen original de Ntra. Sra. de los Desamparados (Valencia, 1978), p. 45. Es una cita de José Rodrigo Pertegás, Historia de la Antigua y Real Cofradia de Nuestra Señora de los Inocentes Mártires y Desamparados (Valencia, 1922).

10 F. M. GARIN ORTiz de TARANCo, «La inconografía original de la advocación mariana de los Desamparados», R.A.E., 1941, p. 5. 
Pueden apreciarse tres etapas:

Siglo XV. Se hace la imagen de pasta liviana, lisa por la espalda para ser llevada sobre los féretros.

Siglos XVI-XVII. Comienza a salir erguida en procesiones y se coloca en el altar para determinadas ocasiones, por lo que se adorna con joyas y se le añade un manto para cubrir la parte posterior.

Siglo XVIII. Se decide su colocación perpetuamente en el nicho del altar y se obra en ella una cirujía total.

\section{Virgenes entronizadas}

Son vírgenes de origen medieval que han sido muy veneradas en una gran parte de la Península. Suelen estar sentadas, aunque algunas se mantienen de pie, y se caracterizan por su sencillez y majestuosidad. Estas hermosas imágenes también fueron revestidas y embutidas en mantos y armazones que las hicieron perder su antiguo aspecto.

La Virgen de Montserrat es una talla de la primera mitad del siglo XII, románica y de aspecto muy simétrico, pero esta escultura sencilla ha estado durante siglos tapada por vestidos y joyas según los gustos de la época. De todas formas, su frontalidad y simetría, al menos en las representaciones en estampas y medallas, son características propias. Se la suele representar con las montañas al fondo a modo de respaldo de su silla, el Niño sobre sus piernas muy centrado, coronada y nimbada y con las ermitas alrededor de la montaña; otros detalles son los pliegues de su túnica y la esfera florida que sostiene en su mano derecha y, como símbolo de Montserrat, se suele colocar una sierra sobre un pico de la montaña. En alguna de sus versiones del siglo XVIII el gran manto tapa la silla y el rostrillo enmarca su cara. Otra de sus célebres características es su tez negra no siempre representada, como ocurre en el metal. La moreneta también fue objeto de modas dieciochescas, en el siglo XIX, cuando aún guardaba Montserrat su tesoro, las tropas napoleónicas encontraron cincuenta vestidos, un número abundante, aunque comprensible por la fama y poder del santuario.

Guadalupe, aunque no es sedente ${ }^{11}$, tiene la misma actitud mayestática y hierática que poseen las vírgenes entronizadas que sostienen en una mano

11 Francisco DE S. JoSEPH, Milagros nuevos... de Nuestra Señora Santa María de Guadalupe (Madrid, 1766), p. 8. 
el cetro y en la otra el Niño, siendo lo mismo que estén erguidas o sentadas. "La famosa imagen es una talla románica, que ha quedado sepultada bajo el enorme montón de sedas y joyas con que la vienen cubriendo sus devotos» ${ }^{12}$.

La Virgen de Guadalupe más difundida en la actualidad es la de México, pero la extremeña fue muy conocida en épocas anteriores; tal vez el final del siglo XVIII y los principios del XIX indiquen el límite de su difusión. $\mathrm{Su}$ figura la reconocemos por un gran manto muy bordado, un tocado y una corona imperial, el Niño que sujeta en su brazo izquierdo tiende al centro y en la derecha lleva un gran cetro, a sus pies una luna creciente.

Una alusión que hace Vilafañe ${ }^{13}$ a que la Virgen va vestida y adornada como emperatriz de los cielos y tierra es interesante, pues ésta es la imagen que se quiere dar de María en el siglo XVIII, de emperatriz cuajada de joyas y riqueza; ya que no existe otro medio para indicar su excelencia, se manifiesta por medio de las riquezas terrenales.

Un dato que nos parece importante para la datación de las medallas de esta imagen es la ofrenda del toisón de oro que pende de su manto durante el siglo XVIII y que fue donado por el Duque de Béjar, Manuel López de Zúñiga, a finales del siglo XVII. Todas las imágenes acuñadas en las medallas de Guadalupe que hemos estudiado, llevan sobre el manto un toisón, excepto una de factura más antigua que, por este testimonio, sabemos debe ser del siglo XVII.

La imagen de la Virgen de Nieva es un caso más de escultura sedente que pierde esta postura durante el siglo XVII en que es completamente transformada, convirtiéndose en una pomposa imagen de aspecto campaniforme, un cetro en su mano derecha y el Niño en la izquierda, el rostrillo que enmarca su cara y una gran corona y nimbo.

Un escrito de un religioso de Nieva del siglo XVII, recogido por Vilafañe dice así:

A 16 de dic. del año 1624 vimos algunos frailes esta santa imagen, que para mejorarla de vestido la descubrió con mucha reverencia, y decencia nuestro Reverendo $P .[\ldots]$ es de madera, y no se puede conocer qué madera sea, por el barniz que tiene; es de escultura, labrado todo el cuerpo con poca curiosidad; mas el rostro es hermoso, algo moreno, puede ser de la mucha antigüedad: la

12 M. TRENS, op. cit., p. 542.

13 J. Vilafañe, Compendio bistórico en que se da noticia de las milagrosas y devotas imágenes de la reyna de los cielos y tierra, María Santíssima (Salamanca, 1740), p. 270. 
nariz aguileña, bien sacada, derecha, y muy proporcionada; las manecitas también en buena proporción, ni muy llenas ni muy flacas; el rostro no es redondo, sino más largo que ancho; está sentada; los pies estrivan como en un estradito, y representa el asiento mas de escaño que de silla; las manos salían poco del cuerpo afuera, sin verse brazos; que los que ahora tiene son postizos; mas no lo eran las manos, que por averse gastado mucho, las tenía envueltas en un lienzo guardadas y escondidas en el pecho. Desde la cabeza a los pies tiene media vara, y un dozaba; sale del lado izquierdo un Niño, no sentado, ni torcido, sino es derecho, mas ladeado un poco, como que se inclina, o reclina al brazo, con una tunicela desde el cuello abaxo; tiene todo el una cuarta escasa; el color de la tunicela es colorado; parece también postizo, como el azul de la tunicela, que de cuello a pies tiene la Madre, con un poco de colorado a un lado; en baxo un manteo, o saya debaxo de otra saya ${ }^{14}$

La Peña de Francia es un tipo parecido a la de Nieva porque antiguamente estaba sentada en una silla, mas luego los mantos y vestidos la enterraron.

En medio del retablo está el trono magnífico de plata, en que se ostenta la gran Señora, la imagen sagrada de María, rodeada de un arco de plata, con lucidísimos rayos; corona imperial de oro, filigranada en la cabeza, y en ella engastadas piedras muy preciosas: Vestidos según los tiempos, de mucho lustre y valor; y pendientes de ellos, joyas muy ricas. Sobresale a la parte exterior del arco, una riquísima cama de plata, con raso, y primoroso arte labrada [...] Es la santísima imagen muy morena; y algunas vezes, se muestra tan agraciada, y hermosa, que arrebata los corazones, y se lleba los ojos hazia si misma: Pero en otras ocasiones (especialmente quando ay tempestades) ostenta un rostro tan severo, y airado, que son pocos los que se atreven a mirarla de hyto en hyto. Dízese, que está sentada en una silla, y que tiene al Niño Jesús pegado al pecho, siendo Hijo, Madre, y silla, de una misma pieza. De los que oy viven nadie la ha descubierto, porque ai tradición de que un prior, quiso registrar la materia de que estava fabricada, (y es de madera sin duda) y la forma que tenía en lo interior; y que quedó allí pasmado, y sin poderse mover: Persuadiéndose, a que era castigo de su devoto atrevimiento ${ }^{15}$.

Esta idea de que la Virgen no puede ser descubierta sin castigo, ni mirada demasiado, hace que la imagen se divinice y se haga completamente inaccesible a los humanos.

Una de las características más acusadas de esta imagen es su forma acampanada o piramidal, de base muy ancha, y sus adornos de cintas y lazos sobre la túnica, también lleva rostrillo y una gran corona, de su lado

14 J. Vilafañe, op. cit., p. 370.

15 D. CABAllero, Historia de la admirable invención y milagros de la thaumaturga imagen de Ntra. Sra. de la Peña de Francia, patrona tutelar y defensora de Orán (Salamanca, 1728), pp. 78-80. 
izquierdo sale el Niño. Todo ello le da un aspecto muy geométrico y simple de representar.

\section{ICONOGRAFÍA DE LOS SANTOS}

De los santos importan más sus reliquias que las imágenes que los representan; a veces ambas cosas se unen en las llamada imágenes-relicario. La iconografía de los santos recoge momentos o elementos de las leyendas para reproducir a modo de instantáneas lo más sobresaliente o reconocible de sus vidas. Cada época elegirá una serie de clichés para repetir, pero también puede ser importante el medio en que se elabore la imagen para que se haga de una u otra manera: las estampas, por ejemplo, se prestan a lo narrativo, a recoger un pequeño compendio de viñetas; en cambio, las medallas no facilitan la narración, pues necesitan una única imagen de rasgos muy fuertes para que sea inconfundible. Algunos relicarios sirven como modelo para reproducir un santo: así, el busto-relicario de San Andrés de Teixido es el que sirve de modelo para las medallas; y la cabeza-relicario de San Gregorio Ostiense, revestida de plata, es la que se reproduce en muchas estampas.

De San Gregorio Ostiense es común la reproducción de escenas de su vida, pero también, su cabeza, o atributos episcopales. En una estampa que acompaña el libro de Andrés Salazar, donde se cuenta la vida del santo, aparece vestido de obispo en medio de un paisaje rural, apacentando ovejas cercanas a un río, en el que se lee «río Ebro», y un puente que lo cruza, y a su izquierda muchas langostas en el aire; al fondo se ve un pueblo con su iglesia y las montañas ${ }^{16}$. En este grabado del siglo XVII aparecen consignadas las actividades que, según la leyenda, llevó a cabo San Gregorio.

Creo que es importante conocer cómo es un santuario en una época determinada, para reconocer la iconografía de su santo titular en ese mismo tiempo. Por ejemplo, cómo es el retablo de la iglesia de San Gregorio:

En él está esculpida y pintada gran parte de la vida y muerte del santo; en que se gastó grande suma de ducados [...] En medio del de San Gregorio está el sagrado cuerpo de nuestro gran patrón San Gregorio, sobre donde la custodia del santísimo sacramento. $\mathrm{Y}$ como los ya dichos devotos cofrades del santo han tenido siempre $[\ldots]$ fervorosa devoción $[\ldots]$ no se han contentado en tenerle en

16 A. SAlazAR, Vida y milagros de San Gregorio obispo ostiense y de Santo Domingo de la Calzada (Pamplona, 1624). 
aquella arca [...] le han labrado otra riquísima de plata muy acendrada, en que está esculpida gran parte de la vida del santo... ${ }^{17}$.

Además de este arca con reliquias que se mandó hacer en el siglo XVII, está la cabeza engastada en plata y dorados los extremos. Ambas piezas se sacan en procesión y luego se guardan en un sagrario o alacena situado en el medio del retablo del altar mayor que es muy grande, y todo él de escultura y maravillosamente pintado.

Creo que estampas y medallas, como objetos de gran difusión que son, intentan plasmar o aprehender de una forma sencilla elementos, partes del santuario. Del marco del santuario de San Gregorio surgen los motivos iconográficos que aparecerán luego en nuestras pequeñas obras de difusión.

El modelo iconográfico más importante de San Andrés de Teixido es el busto relicario dorado, pequeña imagen del Renacimiento italiano, con largas barbas y ropajes plegados que dejan ver su mano derecha, sosteniendo un libro, y la izquierda con una cruz aspada (símbolo universal de San Andrés); en el centro del pecho lleva un relicario afiligranado que contiene una reliquia del santo. Parece ser que esta reliquia fue traída por caballeros de la orden de San Juan, pero no se sabe cuándo ni cómo.

El santuario de San Andrés de Teixido tuvo unas pinturas murales en la cabecera de la iglesia que representaban el martirio del santo, de hechura y gusto arcaizante. Estas pinturas fueron tapadas por el retablo que se colocó sobre ellas en el siglo XVIII y que es el que hoy perdura, de estilo barroco gallego: en el centro o camarín del retablo hay una imagen de San Andrés de vestir, con manto y túnica; de su cinto cuelga una sardina de plata.

De San Andrés de Teixido no he encontrado medallas, ni estampas del siglo XVIII, pero sabemos de su existencia por la mención que hace de ellas el Libro de cuentas que se conserva en la rectoral de Teixido, y también por un dibujo que incluye Maciñeira en uno de sus libros sobre el santuario ${ }^{18}$ que representa la efigie de San Andrés fundida en bronce, y que aún se vendía en este siglo en esa forma. Las medallas actuales reproducen el modelo del San Andrés del relicario.

17 Ibid., pp. 242-243.

18 F. Maciñeira, San Andrés de Teixido (La Coruña, s.a.), p. 81. 
En el santuario de Santa Casilda de Burgos (Buezo) había varios elementos que nos pueden ayudar a reconstruir su iconografía, por ejemplo, unas pinturas murales con la vida y milagros de la santa que se renovaron en 1644 y en 1750 .

De 1529 a 1750 las reliquias y el altar de Santa Casilda estaban en la nave del lado del evangelio, ya que el central aún lo ocupaba San Vicente. Esta capilla era de la siguiente forma:

El retablo es muy curioso, mandóle hazer y dorar a su costa D. Juan Fernández Zorrilla, cavallero del Ávito de Santiago, [...] año de mil seiscientos quarenta y quatro, y puso en él alguno de los cuadros del antiguo, en que están pintados algunos de los milagros, que refiero en su vida, y en el nicho de en medio está la santa de bulto, recostada sobre el brazo derecho, como si estuviera en la cama. La cubierta es de tela de oro, adornada con diversas alhajas de plata y oro, como son Agnus y joyas, que le dan dado sus devotos. Cubren el altar unas cortinas de tela muy preciosa, y fuera tiene unas arañas de plata. Debaxo de esta santa imagen está una urna, con tapa de piedra toda dorada, la qual cierran tres candados [...] y dentro de esta urna está el cuerpo de nuestra santa, y abaxo en craticula un relicario de plata con su peana, y dentro de él unas reliquias, que son una cinta de la santa, parte de su mortaja, y cabellos, roxos como un halambre, y unos huesos de San Vicente Mártir, y de San Bartolomé Apóstol [...] A lo último de esta capilla, al lado del Evangelio, azia el poniente, ay una imagen de piedra [de esta santa] dorada, y pintada, embutida en la pared, y es la que antiguamente estaba sobre su sepulcro... ${ }^{19}$.

Así que para rehacer la iconografía de esta santa tenemos en su santuario dos imágenes, una recostada y otra de bulto, dorada y pintada. Además consta que en el retablo en cuadros se contaban los milagros que narra Cantón Salazar en su libro: el de las rosas, el del demonio en el puente, la tempestad, etc.

Después de 1750 las reliquias y la imagen recostada de Santa Casilda pasan al altar de la nave central, y se construyó un nuevo retablo más adornado que el anterior; así lo cuenta el P. Flórez y Martínez López en su historia de Santa Casilda; el documento que describe esta traslación al altar central de las reliquias de la santa se guarda con las llaves de la urna en el Archivo de la Iglesia metropolitana de Burgos.

Además de estos detalles, existen otros elementos interesantes de la iconografía de Santa Casilda como son una estrella que aparece a veces en sus medallas y que se representa en la pared de la entrada de su santuario, en memoria de la que la guió. El símbolo de la Iglesia metropolitana de

19 J. Cantón Salazar, Vida de Santa Casilda (Burgos, 1724), pp. 254-255. 
Burgos es una jarra de azucenas, éstas aparecen en la pared de entrada del santuario y también en el reverso de las medallas de Santa Casilda.

\section{LAS INSIGNIAS O RECUERDOS DE UN SANTUARIO}

Las insignias y recuerdos de un santuario son objetos recreadores y plasmadores de una iconografía muy extendida y por tanto importante. En este apartado vamos a reducirnos al estudio de estampas sueltas y medallas, aunque hay otros muchos objetos que podrían incluirse. En principio consideraremos los privilegios de fabricación y venta y los canales de mercado de estos objetos, luego pasaremos a su conocimiento descriptivo y formal, y finalmente veremos para qué se usan y cómo se sirven de ellos los devotos.

\section{Medallas de devoción}

Un objeto tan común en nuestra cultura y tan poco estudiado por los españoles atrae la atención. ¿Qué hay tras esos pedacitos de metal sagrado?

Dentro de la numismática en general se ha tratado de estas medallas como de un apéndice insustancial, ya que ha interesado más el estudio de medallas conmemorativas y honoríficas. La única definición amplia que he encontrado de ellas es la de la New Catbolic Encyclopedia: "Una medalla religiosa es una pieza de alguna sustancia sólida generalmente, pero no necesariamente metálica, en forma de moneda, adornada con alguna inscripción religiosa o imagen, usualmente para ser llevada suspendida del cuello» ${ }^{20}$. El uso de estos objetos devocionales se remonta a tempranas épocas del cristianismo (siglo IV) y se desarrolló con la práctica de dar a los neófitos una medalla conmemorativa de su Bautismo. Del comienzo de la Edad Media no hay ejemplos seguros, pero a partir del siglo XII la costumbre creció al usarse como «signo de peregrinaje» en Roma, Canterbury, Santiago de Compostela y Tierra Santa. Las medallas religiosas como hoy las conocemos comienzan a aparecer en el siglo XVI, la bendición de medallas comenzó a hacerse por estas fechas y su uso se expandió rápidamente. En el siglo XVII cada ciudad tenía sus propias medallas: los pasajes de la vida del Señor, las apariciones de la Virgen y los santos eran conmemorados en medallas de todas clases. Además de ser bendecidas, las medallas pueden estar cargadas de indulgencias como ocurre a veces con las

20 P. F. MULHERN, «Medals, religious», New Catholic Encyclopedia (Washington, 1967), vol. IX, p. 547. 
del Niño Jesús, Medalla Milagrosa, de Ntra. Sra. de Guadalupe y de San Bernardo y San Benito. Las medallas pueden tener un uso mágico o de amuleto, lo que ha sido muy atacado por la Iglesia. Es obligación del ordinario local ejercitar vigilancia sobre la manufactura y venta de medallas, como de otras imágenes religiosas, en orden a excluir cosas ajenas a la fe, o conducentes a prácticas supersticiosas ${ }^{21}$.

\section{Privilegios de fabricación y venta}

Algunos santuarios tuvieron el privilegio de fabricación de medallas y otras imágenes desde muy antiguo, tenemos noticias de cómo era la situación en el siglo XVIII en lugares como Santa María de Nieva, Guadalupe, San Andrés de Teixido y algo de Peña de Francia y Montserrat, además de la normativa de Carlos III al respecto, que sirve para todos.

Al convento de Santa María de Nieva corresponde privativa y legítimamente imprimir, fundir y vender estampas y medallas con el título de su Virgen, o en todo caso dar licencia al platero o impresor que quiera hacerlas; este derecho fue dado por Felipe V en 1733. Y la causa que justifica que el convento tenga este privilegio es el hecho de que estampas y medallas deben estar tocadas a la mano derecha de la imagen de la Virgen «donde el poder de su precioso Hijo la tenía formada la figura o materia de un rayo, hiban seguras de qualquier peligro» ${ }^{22}$. En cambio, las que habían sido hechas sin estar tocadas a su original no tenían el poder de librar de rayos y centellas, por lo que se tenían como fraude hacia los devotos.

Los puntos de venta y distribución de estampas y medallas de Nieva, además de la casa central de Santa María, eran otros conventos dominicos: el del Rosario de Madrid, el de San Pablo de Valladolid, y Santa Cruz de Segovia. Las quejas de los dominicos de Nieva se centraban en el hecho de que muchos plateros e impresores segovianos y de otros lugares de España fabricaban muchas estampas y medallas con el título de la Soterraña de Nieva, y por ello consiguen del Rey esa carta que los convierte en los únicos productores de estas imágenes, o legitimadores de ellas. No sabemos si se daba licencia a muchos impresores y plateros y en qué condiciones se hacía, lo que sí conocemos son circulares de aviso de la normativa que se mandaban a estos artífices e incluso a los buhoneros de Segovia, San Sebastián, Alcalá de Henares, Granada, Córdoba, Ávila, Arévalo.

\footnotetext{
${ }^{21} \quad$ Ibid., p. 547.

22 A.H.N. Clero: legajo 6285 (s.f.).
} 
En 1768 hay una nueva advertencia en la ciudad de Córdoba donde se siguen vendiendo, imprimiendo y fundiendo estampas y medallas sin licencia $y$, por tanto, sin tocar a la verdadera imagen, por lo que se advierte del requisamiento de tales muestras a estamperos, impresores y plateros, cosa que se llevó a efecto ${ }^{23}$.

En 1771 se produce un hecho de vital importancia para el desarrollo de la platería española: la promulgación de la Real Cédula de 10 de marzo, con normas que tratan de ser uniformes para todo el reino. Esta normativa nos atañe porque hay dos capítulos dedicados específicamente a la fabricación de cruces, medallas, relicarios y otros objetos religiosos menudos ${ }^{24}$. A partir de esta fecha queda prohibida la fabricación y tráfico de cruces y medallas de plata que no estén hechas por artífices plateros con tienda abierta y queda prohibido también hacerlas de baja ley. Se exceptúan de esta ley general las iglesias y comunidades que acostumbran a repartir cruces y medallas de devoción, poniéndose el ejemplo de Nieva, centro que debió de ser importantísimo productor y vendedor de medallas. De todas formas, los religiosos han de atenerse a la ley general de no fabricar objetos de baja ley.

De la pragmática se deduce que hay plateros que trabajan realizando medallas para iglesias y comuniddes, siendo éstas más bien las expendedoras, y los plateros los fabricantes. De todas formas, hay comunidades que labran sus propias medallas y las venden, éste es el caso de Santa María de Guadalupe.

En el A.H.N. hay un Libro del Convento de Guadalupe sobre "Compras de plata de medallas e ingresos de demandas», relativo e los siglos Xvill$\mathrm{XIX}^{25}$. Se trata de un documento de enorme interés (aunque muy enmarañado y con muchos asuntos a la vez), en el que hay datos y cuentas de las hechuras de medallas y de estampas a lo largo de un siglo. De este libro hemos sacado los tipos o hechuras de medallas, sus precios, metales con que se fabricaban, y también hemos averiguado que Guadalupe a veces contrataba plateros para estas obras, pero en algunas épocas los mismos religiosos las realizaban. Parece ser que en el siglo XVIII la platería guadalupense no es muy conocida y debió ser un siglo irregular para este tipo de producción, en cambio se conoce mucho mejor a Guadalupe como un emporio artesanal en el s. XVII:

\footnotetext{
${ }^{23}$ A.H.N. Clero: legajo 6281 (s.f.).

24 A.H.N. Consejo: libro 1514 n. 69 (s.f.). Ver la Real Cédula, Anexo.

25 A.H.N. Clero: libro 1578 (s.f.).
} 
porque es imposible saber a cuánto se extendió el movimiento y trabajo de los plateros guadalupenses sexcentistas, siendo una de las principales ocupaciones la acuñación y labra de medallas de Ntra. Sra., en oro, plata y bronce, para venderlas por la feria de septiembre y durante el año, variando casi todos el tipo de acuñación ${ }^{26}$.

A partir de 1777 y por una temporada se fabricaron en el monasterio las medallas de Guadalupe:

En 20 de octubre de 1777 el Rdo. P. Fr. Alonso de la Torre Arquero Mayor de este Real Monasterio de Ntra. Sra. Sta. María de Guadalupe dispuso, por motivos especiales que le asistían para ello, se hiciesen en este oficio de arca las Medallas de plata, para que corriese por mano de los PP.es Arqueros de plata con que se fabricavan, y se supiese ivan trabajadas con la ley que corresponde y haviéndose hecho quarto aparte para ello, con su fragua y trastes necesarios, se dio principio a hacerlas en este día por Juan Cubillo, y Antonio Joseph Barela ${ }^{27}$.

En 1785 muere Barela y, a partir de entonces, no hay más datos de la producción de medallas en el monasterio (es posible que acabara la fabricación por estas fechas) y en 1797 ya hay cuentas de compras de medallas a Juan Hermida, platero.

Durante los años de acuñación de medallas en el monasterio la producción es grande llegando a fabricarse unas 1.000 medallas al mes. La tipología es difícil de distinguir; se habla de diferentes precios por tamaños: medallas nuevas, de arco, de arquillo, grandes, chicas, ochavadas, gordillas, etc. Siendo o todas de plata o bien doradas con el cerco de plata.

Había también medallas de bronce de hechura más común y de precios más asequibles que las otras:

2 de septiembre de 1741 se recibieron de Juan Bautista el maior 238 medallas de arquillo, 1998 pequeñas de bronce por cuio importe se le pagaron 218 r. y $10 \mathrm{~m}$. En 5 de septiembre se pagó a Gerónimo de Luna 165 r. $24 \mathrm{~m}$. por las hechuras de 574 medallas de arquillo y 730 pequeñas ${ }^{28}$.

Éstas son cuentas abultadas por ser fechas anteriores a la fiesta de la Virgen (8 de sep.) cuando se esperaba la mayor afluencia de gentes.

Aparte de adquirir a los plateros, por la feria de la Virgen, plata, oro y a veces las medallas ya hechas, el monasterio compraba medallas a Roma; tenemos noticias de estas compras de los años 1742 a 1828, aunque no

26 G. RuBIo, Historia de Ntra. Sra. de Guadalupe (Barcelona, 1926), p. 436.

27 A.H.N. Clero: libro 1578 (s.f.).

${ }^{28}$ A.H.N. Clero: libro 1578, fol. 104. 
era muy continuado el trasiego se importaban grandes cantidades. Es posible que esta compra a Roma tenga que ver con alguna bendición especial dada por el Sumo Pontífice a las medallas.

Los jerónimos de Guadalupe pagaban o cumplían con algunas gentes dándoles medallas y otros objetos similares, de hecho el Libro de medallas de Guadalupe tiene un capítulo dedicado a medidas y medallas de cumplimiento que se entregaban a personajes como los reyes, a Capitanía general, a Comandancia, a otros monjes jerónimos, para agasajar al Consejo de la Mesta, etc. Las medidas supongo que son medidas de la Virgen, esto es, cintas de la medida exacta de la imagen de Ntra. Sra., junto con las medallas eran los recuerdos más comunes de Guadalupe.

Del santuario de San Andrés de Teixido sabemos que el responsable de entregar y vender estampas y medallas del santo era el prior de Régoa, que administraba los bienes de Teixido dando cuenta de sus rentas de limosnas al procurador de Puertomarín (de la Orden de San Juan de Jerusalén). Especial interés tenían las cuentas que se producían en la época de mayor aglomeración de romeros, del 15 de agosto al 8 de septiembre. A causa de la poca claridad de estas cuentas pleitea el comendador de Puertomarín con el prior de Régoa en el siglo XVIII (1775-1781). Dentro de las limosnas se consideraba el dinero que se daba por estampas y medallas, e incluso por la cera, y todos estos caudales iban a parar al prior que los administraba como mejor le parecía. Pero en este momento se intervienen las limosnas y el prior se defiende diciendo que tenía facultad para la venta de las citadas imágenes con la mera obligación de dar tres arrobas de aceite para el santuario ${ }^{29}$. Al final del pleito lo único que se pide al prior es que asiente cada día el número de limosnas y el producto sacado de las estampas y medallas que entrega, para que haya noticia de lo ganado cada año. Lo que parece claro es que estampas y medallas no se venden a un precio fijo, sino que se dan en la romería y otras fiestas a cambio de la limosna ofrecida por el devoto.

No tenemos noticia de dónde se realizaban estas medallas y estampas, que encargaría hacer el prior de Régoa a plateros y grabadores gallegos. ¿Tal vez era Santiago la proveedora, cuna de grandes plateros y grabadores?

De la Peña de Francia el único documento que tenemos es la comunicación del prior del convento que paga ciertos trabajos a justicias y guardianes de la feria de septiembre con medallas: «A éstos los mantiene la comunidad en dichos días; y se les da de gratificación algunas medallas, y

29 Libro de cuentas de la Rectoral de Teixido. 
medidas de la Viryen, a proporción de los sujetos» ${ }^{30}$. Así que las medallas aún tenían un valor semejante a la moneda, pues los religiosos las entregaban a cambio de trabajo y de otros débitos, y también como intercambio por la limosna ofrecida.

En la Peña de Francia también se vendían medallas a peregrinos y visitadores:

Al lado derecho del coro en lo vajo, está la sacristía vieja, y al siniestro lado la cerería, en donde se dan o escriben las limosnas de los votos; y se dan también Medidas y Medallas de Ntra. Sra. y ay Efigies de cera, que según el voto de cada uno, las paga, y las pone tiempo determinado en el altar de Ntra. Sra. ${ }^{31}$.

Montserrat fue otro gran centro expendedor de estampas, medallas y otros objetos: «Sabemos que de tiempo inmemorial, quienes retornaban de Montserrat mostraban en lugar visible medallas, rosarios, escapularios, etc., en señal de su devota excursión» ${ }^{32}$. Entre los recuerdos que se llevaban de Montserrat, aparte de los que se conseguían en la abadía, estaban los trabajos realizados por los ermitaños de la montaña que eran rosarios y cruces de boj. Las cruces son especialmente curiosas, grabadas con los instrumentos de la Pasión y suelen llevar la fecha en que fueron hechas y el símbolo de Montserrat, una montaña con una sierra. En el Museo del Pueblo Español hay varias cruces de boj pertenecientes a los siglos XVII y XVIII, y en el Museo de Artes Decorativas hemos visto algunas que debían ser bastante comunes en los hogares españoles en los pasados siglos.

\section{Caracteristicas materiales y formales}

Las medallas suelen ser de metal, bien noble como el oro y la plata, o bien aleaciones u otros metales menos nobles como cobre, aluminio, etc.; pero también las hay de otros materiales como azabache, pizarra, esmalte. Dentro de la selección que hemos realizado predomina la plata como primer material, luego el bronce, una pequeña muestra de medallas de pizarra de Nieva y una de esmalte de Montserrat.

Las medallas de pizarra de Nieva son un tanto particulares. Provienen de trozos de pizarra sacados del lugar donde se dice que se encontró la imagen, por lo que tienen un valor como de reliquia, y además es la señal de 1806 .

30 A.H.N. Clero: legajo 5801 (s.f.). Este dato está sacado de la feria de septiembre

31 D. Caballero, op. cit., p. 78.

32 A. Albareda, Historia de Montserrat (Montserrat, 1974), p. 171. 
que dio María al pastor de su aparición. Las gentes que iban a Nieva de romería o peregrinación entraban en la cámara subterránea que hay debajo del altar para recoger trozos de pizarra, que luego grabarían con la imagen de Ntra. Sra. y engastarían en plata u otro material (ver pieza: M.P.E. n." inv. 2614).

La mayoría de las medallas estudiadas son de plata, material muy común por no alcanzar tan alto precio como el oro y a la vez ser bastante duradero. Algunas medallas combinan bronce y plata, dando un resultado muy bello, como ts el caso de algunas de Guadalupe (ver lám. II,1 a y b).

Las formas de las medallas se reducen básicamente a dos tipos: las llamadas de media hechura, que son figuras silueteadas de las imágenes y las de una pieza maciza a manera de moneda, muy abundantes. Todos los ejemplares que podemos encontrar son diferentes modalidades de estos tipos a los que se añaden adornos, orlas o marcos: de la combinación de la figura de media hechura y el marco surge una medalla calada muy bella, ya que el marco resalta la figura (véase M.P.E. n.o inv. 12429). Las medallas macizas, cuando se adornan con alguna orla, resultan más barrocas y ricas; éste es el caso de algunos ejemplares guadalupenses (véase M.P.E. n. ${ }^{\circ}$ inv. 11790). Por último, encontramos la combinación de medalla y relicario.

En cuanto a las imágenes e inscripciones que aparecen en las medallas tendremos que tener en cuenta anverso y reverso. En el anverso se representa la figura principal a la que está dedicada y a veces también su título, aunque otras éste va en el reverso, grabado el nombre completo, las iniciales o bien una única letra, como es el caso de la Peña de Francia a la que se distingue por una $F$.

En el reverso, además del título, pueden aparecer símbolos o imágenes que nos recuerdan la comunidad religiosa a que pertenece el santuario y la imagen: las medallas de Santa Casilda llevan el jarrón de azucenas, símbolo de la Iglesia metropolitana de Burgos; las de Nieva, la cruz de los dominicos o bien las armas de la Inquisición; las de Montserrat se complementan con la imagen o la cruz de San Benito; las de Guadalupe llevan en su reverso a San Jerónimo; Jesús Nazareno de Medinaceli porta en su reverso a San Félix Valois, uno de los fundadores de la orden trinitaria. De estos datos podemos deducir que los santuarios que pertenecen a una orden religiosa relacionan o vinculan la imagen de devoción con la comunidad que la guarda, en un gesto o signo de propiedad. En los casos de imágenes no guardadas por regulares, sino que pertenecen a cofradías, como la Virgen de los Desamparados (Valencia) y la Virgen de las Angustias (Granada), en el reverso de las medallas se representan santos o patronos de las ciudades donde están ubicadas. En las medallas de la Virgen de los Desamparados encontramos a veces la figura de San José, y en la de las 
Angustias la de Jesús Nazareno, otra imagen de la Pasión relacionada con ella.

La representación de la imagen principal, aunque sea muy esquemática y pequeña, tiene abundantes detalles por los que se reconoce e incluso puede datarse. Por ejemplo, la Virgen de los Desamparados tiene la inclinación perceptible de su cabeza hacia abajo, y un detalle que parece insignificante, como son unos jarroncitos que adornan la peana y que fueron colocados a finales del XVIII y estuvieron allí hasta principios del XIX, nos ayuda a datarla.

En general, las imágenes de vírgenes tienen una forma acampanada o piramidal característica y propia, producto de los mantos que llevan, y suelen sostener un cetro o una flor en la mano derecha, mientras con la izquierda sujetan al Niño. El tocado se limita a una toca o velo, como Montserrat (M.P.E. n. ${ }^{\circ}$ inv. 12531; ver lám. I 1 a y b) y Guadalupe (M.P.E. n. ${ }^{\circ}$ inv. 11790); o bien una toca en forma de rostrillo como casi todas las de Nieva (M.P.E. n. ${ }^{\circ}$ inv. 1698, ver lám. I 3 a y b) y las de la Peña de Francia, ver lám. I 2 a y b (M.P.E. n. ${ }^{\circ}$ inv. 12429). La de los Desamparados lleva desde el xviII una larga melena y sobre ella corona y diadema, las otras llevan sobre el tocado o velo la corona y la diadema o bien una sola cosa. Los adornos sobre el manto también las caracterizan: la Peña de Francia se distingue por unos lazos y cintas que se entrelazan (M.P.E. n. ${ }^{\circ}$ inv. 11284), la de Guadalupe viste un manto bordado y con joyas, entre las que destaca el toisón (del que nos hemos servido para saber que había una medalla del siglo XVII, pues esta ofrenda la llevaba la imagen después de $1686 \mathrm{y}$, por tanto, una representación en que no aparezca será anterior a esta fecha); la Virgen de Montserrat, en cambio, lleva un manto más amoldado a su anatomía y más simple (M.P.E. n. ${ }^{\circ}$ inv. 12531).

Las peanas que las sostienen son en forma de creciente lunar, una nube, u objetos menos celestes, como pueden ser una especie de plinto más o menos adornado o una peana transportada por ángeles (M.P.E. n. ${ }^{\circ}$ inv. 12429).

Las medallas de santos presentan la misma casuística en cuanto a formas y materiales. De Santa Casilda tenemos tres ejemplares de plata que son piezas circulares y ochavadas con algún adorno alrededor; dos de las imágenes representan a Santa Casilda tumbada (ver pieza M.P.E. n. ${ }^{\circ}$ inv. 11227) y la otra es un busto con la palma de martirio, se trata de una imagen que no corresponde a Santa Casilda y que fue utilizada como modelo para diferentes santas. La representación de Santa Casilda tumbada es la que aparece en su santuario en el altar central sobre sus reliquias, llevando una cruz en la mano izquierda y un libro en la derecha; su sueño no es 
real, sino simbólico, rememorando la leyenda ${ }^{33}$. Los sueños la condujeron a una nueva vida; fueron la llamada a los Lagos de San Vicente, una vida retirada, dormida para el mundo pero despierta para la fe.

Finalmente, las medallas de los cristos de Burgos y de Medinaceli. Las insignias del Cristo de Burgos más corrientes son los pequeños crucifijos o crucetas que no hemos incluido, las medallas en forma de corazón son más raras aunque el Cristo que se sobrepone en ellas tiene las mismas características que en las otras: un crucificado con la cabeza inclinada al lado derecho, largo faldellín y tres huevos de avestruz a los pies. El corazón con dos flechas clavadas forma parte del escudo de los agustinos (véase M.P.E. n. ${ }^{\circ}$ inv. 1760).

Al Cristo de Medinaceli se le reproduce de busto, vestido con su túnica, el escapulario, las manos atadas delante, la larga cabellera y la corona de espinas (véase M.P.E. n. ${ }^{\circ}$ inv. 11346).

\section{Estampas}

Las estampas presentan unos modelos iconográficos similares a los de las medallas, pero claro está que al variar el medio material cambian las posibilidades expresivas. En las estampas grandes se pueden contar historias en pequeñas viñetas que se colocan en los bordes alrededor de la imagen con un pequeño texto, y en la parte inferior suele haber una cartela explicativa que nos ayuda a conocer lo representado. Su estudio se facilita porque muchas de ellas llevan fecha y el nombre del grabador y el dibujante.

Las estampas, al igual que las medallas, son entregadas en los santuarios cuando se ofrece una limosna; también eran repartidas por los cuestadores de las cofradías en pueblos y ciudades, e incluso vendidas por estamperos y grabadores en sus tiendas. Los derechos de venta y estampación de algunas imágenes estaban adscritos a un santuario, vedando a grabadores y estamperos fabricar o vender sin el permiso de la comunidad religiosa, como hemos visto que ocurría en Nieva. En otros casos, la cofradía detenta la propiedad del grabado y guarda la plancha de cobre en sus arcas, como es el caso de la cofradía de Jesús Nazareno de Medinaceli, en la que en un inventario de bienes se hace alusión a la plancha de grabado. Aunque la venta y derechos de reproducción los tuvieran algunas comunidades religiosas

33 La historia de Santa Casilda es la de una princesa mora que por sus bondades naturales recibe ayuda divina por medio de dos milagros: primero el de la transformación del pan en rosas y más tarde la llamada divina en la noche mientras duerme, llegando a ser una santa eremita en tierras cristianas. 
y cofradías, la hechura era llevada a cabo por particulares que trabajaban por encargo.

En los siglos XV-XVI Montserrat tuvo imprenta en el monasterio de la que salieron libros, estampas y buletos en grandes cantidades, pero esta actividad duró poco. El resto de los santuarios elegidos no creo que llegaran a tener imprenta propia en esta época, simplemente apalabraban con grabadores de aquí o allá las estampas que querían hacer y pedían una tirada, que luego se vendía en el santuario. No sabemos si los grabadores que trabajaban para un grupo religioso se quedaban con parte de lo grabado para venderlo, ni cómo eran los contratos exactamente. En 1766 hay una orden circular que prohíbe a los religiosos poseer imprenta:

Habiendo entendido el Consejo el abuso, que se ha introducido por algunas comunidades, o personas privilegiadas, de establecer por su autoridad propia varias imprentas, situando algunas dentro de clausura, y en parages inmunes, o cercanos; dando su manejo a personas exentas, contra lo que en este punto está prevenido, y conviene al Estado [...] $\mathrm{Ha}$ acordado que V. en el territorio de su respectivo corregimiento, no permita subsista imprenta alguna en convento, ni en otro lugar privilegiado, o de exempto, ni en sus inmediaciones; y que V. haga saber a los dueños de las que asi hubiere, que en el preciso término de dos meses las vendan, o arrienden a seglares, y las pongan en lugares, o casas distantes de la clausura. Que tampoco permita $V$. que en imprenta alguna intervenga, ni sea regente de ella, Religioso, clérigo, ni otra persona privilegiada; sino es que precisamente corran, y estén todas al cargo, y responsabilidad de seculares sujetos a la jurisdiccón Real ordinaria ${ }^{34}$.

De esta cédula podemos deducir que había bastantes imprentas en monasterios y otros lugares eclesiásticos contra las que toma medida la administración de Carlos III, ya que no reportan beneficios al Estado. Es interesante comparar esta ley con la de la platería de 1777, mucho más permisiva con los privilegios seculares de la Iglesia en cuanto expendedora de insignias como medallas y cruces. Así que en conventos, monasterios e iglesias podrá haber platería y factura de medallas y otros objetos religiosos, pero no imprentas que necesariamente estarán en manos de laicos.

La estampa religiosa será hecha por grabadores independientes que trabajarán para una serie de clientes particulares, siendo éstos en muchos casos religiosos. Tenemos datos de encargos hechos por comunidades religiosas como Guadalupe, Sta. María de Nieva y Peña de Francia.

${ }^{34}$ A.H.N. Consejo: libro 1483 , n. 44 (s.f.). 
En el «Libro de compras de plata de medallas e ingresos de demandas» ${ }^{35}$, del que hemos hecho mención anteriormente, hay un gran apartado dedicado a las estampas y su impresión, gastos y encargos de 1742 a 1832, casi un siglo de historia de las estampas de Guadalupe. Del año 1777 tenemos las siguientes noticias:

En carta de 19 de septiembre avisó el Padre Procurador haber pagado a Ricarte gravador de láminas en Madrid 1364 rr los 400 por abrir una lámina en quarto de Marca mayor cobre $\mathrm{H}^{2}$ para ella $=400$ reales en dos resmas de papel a 10 rr la mano, para 4 estampas $=480 \mathrm{rr}$ por estampar dichas estampas a $12 \mathrm{rr}$ el ciento $=36 \mathrm{rr}$ por dos cajones para traerlas $=$ y $48 \mathrm{rr}$ en $18{ }^{2}$ y $3 / 4$ de rasso liso a $24 \mathrm{rr}$ para dos estampas de la historia y $6 \mathrm{rr}$ del estampado de ambas $1364 \mathrm{rr}^{36}$.

Desde esta fecha hasta fines del siglo XVIII, aparte de Hipólito Ricarte, grabador madrileño, los jerónimos hacen encargos a Félix Prieto de Salamanca y Mateo González de Zaragoza. Veamos algunas de las cuentas con estos grabadores:

- Con Hipólito Ricarte en 1788, 19 de junio: Impresión de 100 tafetanes de la lámina del retablo, 1181 rr y $8 \mathrm{~m}$. Impresión de 50 láminas de tafetán de la $\mathrm{H}^{\mathrm{a}}$. En raso 30 láminas del retablo, 20 láminas de raso de la Hist. 1006 rr y $8 \mathrm{~m}$.

En 24 de julio de 1778: 200 tafetanes y rasos, 600 rr, 18 rr por el cajón en que vinieron de Madrid, $20 \mathrm{rr}$ por el encerado del forro, $8 \mathrm{rr}$ por el porte del cajón de Madrid a Guadalupe. Impresión en papel: 1.000 estampas de la Hist. 10.000 de las chicas, 3267 rr y $17 \mathrm{~m}$.

- Con Félix Prieto, en 1783: Por el retoque de una lámina le pagan 275 r, más doce que costó conducírsela desde Madrid, 287 r. De esta lámina se encargan 3.000 estampas de a real en 1784 .

Por estas fechas el monasterio también ancarga 3.000 libros de milagros hechos en Madrid, que costaron $10.465 \mathrm{r}$.

- En 1786 se paga a Félix Prieto por el dibujo de una lámina de la Historia $300 \mathrm{r}$, y cinco láminas de cobre para cinco láminas nuevas, 320 r. Y por estampar 625 de pliego entero de marca de la lámina de la Historia, a $60 \mathrm{r}$ el ciento $=375 \mathrm{r}$. Por estampar 130 rasos pequeños de la Granadina a real cada uno $=130 \mathrm{r}$. $297 \mathrm{r}$.

- En 1788 Félix Prieto abre dos láminas en dos planchas grandes =

- En 1789 los datos escritos en nota son los siguientes:

35 A.H.N. Clero: libro 1578, fol. 165-183.

36 lbid. 
Según la cuenta del P. Procurador de Madrid de 10 de agosto de 89, resulta haver dado a Félix Prieto $2.000 \mathrm{r}$ a quenta de la lámina de medio pliego que está abriendo $=$ los que se descargarán quando se acave de pagar $=$ se descargaron por la cuenta en fin del 89.

Item son descargo $1.340 \mathrm{r}$ que a saver: los $1.340 \mathrm{r}$ pagados al gravador Don Félix Prieto en esta forma: los $600 \mathrm{r}$ por el viaje que hizo a Madrid para instruirse del dibujo $=320$ para el viaje que hizo a este Monasterio para tomar noticia puntual de los quadros de la historia, efigie, y trono de N. Sra. y los 40 restantes por sus salarios de 28 dias en la venida, y buelta, a razón de $15 \mathrm{r}=$ 1.340 r. ${ }^{37}$.

Por estos datos tenemos muchas noticias de Félix Prieto que grabó tantas estampas de Guadalupe; las cuentas de 1789 puede que se refieran a la estampa que tenemos en las ilustraciones de la Biblioteca Nacional (n. ${ }^{\circ}$ de inv. 43.367).

Aunque Félix Prieto siguió abriendo láminas para Guadalupe hasta fines del siglo XVIII (1795), tenemos noticias de otro grabador, Matheo González, de la ciudad de Zaragoza, que ha de hacer dos láminas para el monasterio: una de medio pliego con medallas de la historia, y otra de a quartilla «con la condición que han de mejorar a la de medio pliego con medallas que abrió Dn. Félix Prieto en este año de 1791...» ${ }^{38}$. Parece, pues, que había gran competencia por realizar las mejores estampas y por variarlas de una temporada a otra.

Para la Peña de Francia también trabajó Félix Prieto, del que tenemos una estampa de la Biblioteca Nacional ( $n .^{\circ}$ inv. 14.101) fechada en 1781 y muy semejante a las guadalupanas. Del mismo hay otra estampa de 1756, sobre la que nos da referencia el P. Colunga:

De las estampas de la imagen que nos han quedado del siglo xvill hay una que lleva la fecha de 1756 y fue grabada por Félix Prieto en Salamanca. La imagen se nos presenta en la forma de una pirámide de base ancha, cubierta de rico manto y adornada de un collar que pende del cuello. La cara va encuadrada en un rostrillo, y sobre la cabeza una corona. Todo ello ofrece apariencia de mucha riqueza, pero nos oculta la forma natural de la imagen» ${ }^{39}$.

Anselm Albareda considera tres etapas iconográficas en las estampas de Montserrat. Los primeros grabadores al servicio del monasterio estuvieron bajo la dirección del Maestro Rosembach, en las fechas en que el

37 A.H.N. Clero: libro 1578 (s.f.).

38 A.H.N. Clero: libro 1578 (s.f.).

39 A. Colunga, Historia del Santuario de Ntra. Sra. de la Peña de Francia (Salamanca, 1944), p. 41. 
monasterio tuvo imprenta propia; de esta primera etapa tenemos estampas de boj. En el Renacimiento la estampa se rodea de una orla con adornos de la época; y en los siglos XVII y XVIII se pasa a unos pequeños cuadros con milagros de la Virgen. También existen aguafuertes milaneses de principios del XVIII.

Sobre las estampas de San Gregorio Ostiense tenemos datos de lo que se ordenó hacer para 1756 con motivo del largo viaje de la cabeza de San Gregorio por gran parte de la Península, para combatir la langosta:

Unos días antes de salir se ordenó al impresor de Pamplona Martín Joseph de Rada la preparación de estampas y formularios. Se imprimieron 3.680 estampas medianas, 2.400 grandes, de ellas tres docenas de tafetán para personas de distinción y 60 manos de papel de oraciones y exorcismos. Todo lo cual importó 500 rls. y 22 mars. ${ }^{40}$.

No hemos econtrado ninguna de estas estampas en la Biblioteca $\mathrm{Na}$ cional; es posible que éstas se guarden en algún archivo o biblioteca de los lugares por donde pasó la rogativa contra la langosta.

La estampa de San Gregorio que adjuntamos en las ilustraciones pertenece al tipo de las que llaman de historia, porque en ella se relata, resumida, la leyenda de este santo sanador (B.N. n. ${ }^{\circ}$ inv. 36.127) y se escenifica el ritual del agua: unos clérigos dan de beber a unos peregrinos. No teníamos noticias de que el agua de San Gregorio sirviera también a las personas, pero en esta ocasión las imágenes nos documentan una práctica usada en el s. XVIII.

De Jesús Nazareno de Medinaceli tenemos documentos que hacen referencia a las láminas de cobre guardadas en el Arca de la cofradía en 1799: «Una lámina grande de cobre que representa a Nuestro Padre Jesús $\mathrm{Na}$ zareno, otra chica que sirve de portada en los manifiestos, doscientas cinquenta estampas grandes» ${ }^{41}$. Y del mismo libro de cuentas de entradas y salidas, se deduce que estampas y escapularios se pagaban « 4 de abril de 1800: se sacaron 48 estampas y dos escapularios uno grande y otro chico. Nota: se introdujeron $80 \mathrm{r} \mathrm{V}^{\mathrm{n}}$ en el Arca, importe de las estampas y escapularios que se citan» ${ }^{42}$.

De Jesús Nazareno hemos elegido dos estampas que contrastan sensiblemente, al ser una bastante popular (B.N., n." inv. 13.544; ver lám. V,1)

40 J. J. Barragán, «Las plagas del campo español y la devoción a S. Gregorio Ostiense», Cuad. de Etnol. y Etnog. de Nav., X (1978), p. 291.

41 A.H.N. Clero: libro 19.674 (s.f.).

42 Ibid. 
y la otra una elaborada imagen del gran grabador J. A. Salvador Carmona (B.N., n. ${ }^{\circ}$ inv. 13.556).

En cuanto a las estampas del Cristo de Burgos, hemos intentado reunir un ejemplar del Cristo de los agustinos (B.N., n..$^{\circ}$ inv. 30.081) y otro de los trinitarios para comprobar las diferencias iconográficas, que son francamente pocas. Aparte de la simbología diferente de cada orden adscrita a cada imagen, contamos con el dato del milagro de las gotas de sangre que derramó el Cristo de los trinitarios en 1366 (B.N., n. ${ }^{\circ}$ inv. 30.082). Existe otra pequeña diferencia: el Cristo de los agustinos tiene la ofrenda de los huevos de avestruz solamente a los pies; en cambio, el de los trinitarios los tiene colocados también suspensos en cada mano.

Las variedades iconográficas que presentan las estampas de Santa Casilda son dos: Casilda vestida de princesa mora, mostrando las rosas a su padre, o bien la imagen de Casilda recostada en su nicho en el altar. En la representación del milagro de las rosas aparecen por un lado los cristianos cautivos y por otro los moros libres y Casilda en medio entre los dos mundos (B.N., n. ${ }^{\circ}$ inv. 43.377). En la representación de Casilda recostada, reconocemos a una santa iluminada por el Espíritu Santo (B.N., n..$^{\circ}$ inv. 14.364; ver lám. VI,1).

Las estampas de advocaciones marianas suelen tener la historia y milagros de la Virgen, contada en texto e ilustrada en las viñetas (véanse B.N., n. ${ }^{\text {os }}$ inv. 14.101, 13.789).

En general, la iconografía que presentamos en las estampas no difiere mucho de la de las medallas; la diferencia estriba en que la estampa tiene más posibilidades. Pero la presentación de una imagen en una época corresponde a unos patrones que se asimilan en todas partes por igual, aunque unas evolucionen por delante de otras. Por otra parte, entre platería y grabado hay todo un mundo de relaciones y conexiones; por ello no es de extrañar la semejanza en las representaciones.

\section{Usos y abusos de estampas y medallas}

Estampas religiosas y medallas de devoción, aunque son objetos materiales muy distintos, tienen finalidades semejantes y paralelas: se cuelgan en las paredes de las casas, se ponen a la cabecera de la cama, se guardan entre los libros de oraciones, o se llevan colgadas al cuello. La estampa es más de tener en casa y la medalla más propia para ser llevada; esto no es impedimento para que a veces ocurra al revés.

Ambos objetos son representación de una imagen y no pretenden tener valor por sí mismos, sino por lo que representan; de ahí que la Iglesia se 
haya pronunciado en muchas ocasiones con respecto a este tema por el temor a la caída en la idolatría. De todas formas, la costumbre de bendecir estampas y medallas, y de cargarlas con indulgencias, ha hecho de estos objetos algo más que un trozo de metal o papel. También el hecho de que hayan sido tocadas por la imagen original les da un valor sobreañadido, son igual que reliquias; en algunos casos el material de que están hechas las medallas aumenta su valor, por ser parte de lo que fue cueva de la imagen sagrada. Debido a esta tradición que las llena de virtud, bien sea como reliquia, bien como fuente de indulgencias y bendiciones, a estampas y medallas se les atribuye poderes extraordinarios.

En los libros de historia y milagros de una imagen se hace siempre mención del valor de sus estampas y medallas. De la Virgen de Nieva se dice que libra de rayos, fuegos y centellas, así como que ayuda a las mujeres en los partos, defiende de los animales ponzoñosos y culebras, y hace engendrar a los que creían no poder:

Son especialmente atendidos de la Magestad divina, los que consigo traen estampa, medalla, medida o pizarra de el sepulcro donde estuvo la sagrada imagen, así lo acredita la continuada experiencia de milagrosos casos ${ }^{43}$

Del Cristo de Burgos también hay testimonios de haber usado su crucifijo para conseguir milagros: «De una muger que estaba en peligro de muerte, con dolores de parto y con la insignia del santo crucifijo fue libre» ${ }^{44}$. Igualmente se cuentan cosas extraordinarias de objetos e insignias de Santa Casilda; son especialmente conocidas las medidas que se ponen las mujeres encinta, sus estampas y medallas:

La tierra que sacan oy del sepulcro donde estaba el santo cuerpo la llevan para curar fiebres, y se ha experimentado con ella muchos milagros, quedando los enfermos libres de ellas, beviendo la agua donde la han echado; y también con sus medidas, y estampas trayéndolas consigo, y encomendándose a esta santa con devoción, como he dicho ${ }^{45}$.

En general, estampas y medallas pueden servir activa o pasivamente de diversas formas:

43 A. Barcaiztegui, Historia de la aparición milagrosa de la imagen de Ntra. Sra. de la Soterraña de Nieva y novena para implorar su auxilio (Pamplona, 1733), p. 121.

44 J. SIERRA, op. cit., p. 117.

45 J. Canton Salazar, op. cit., p. 295. 
Pasivamente: Como objeto-recuerdo de peregrinación o visita a un santuario.

Objeto de devoción, soporte de oración o reflexión.

Activamente: Para ganar indulgencias.

Para conseguir curaciones, milagros.

La utilización que supone en estos objetos un poder activo, es el uso que puede resultar más desviado de la ortodoxia religiosa. El atribuir milagros o curaciones a una medalla, crucifijo o estampa es un hecho que a nosotros, ahora, nos resulta inverosímil, pero que en el siglo XVIII parecía normal, aunque fuera considerado como supersticioso por parte de la Iglesia.

Otro problema plantean las indulgencias que se atribuían a muchas estampas y medallas y que a veces eran falsas, pues algunos grabadores, para vender más, se las inventaban. Contra estas falsas indulgencias, y contra el abuso de su venta en iglesias, se dirigieron muchas prohibiciones del Estado y de la jerarquía eclesiástica, pero sin resultados muy convincentes, pues aparecen una y otra vez las mismas prohibiciones.

\section{A N E X O}

Real Cédula de 10 de marzo de 1771 en que se establecen reglas a todas las congregaciones, y colegios de plateros del Reyno en lo perteneciente a su arte y comercio; que deben ser uniformes en todo el Reyno, comprendiendo al mismo tiempo lo que en particular deba ser propio del colegio de Artífices plateros de Madrid. A.H.N. Consejos: libro 1514, n. ${ }^{\circ} 69$.

Capítulo VIII. De las cruces, medallas y otras semejantes especies.

Haviéndose reconocido que las cruces de Caravaca y otras Medallas de devoción, que se acostumbran repartir, y vender son de baxa ley, y a veces la mitad de cobre, y consumiéndose en esto una gran cantidad de marcos, de que se ocasionan gravísimos daños, se prohíbe absolutamente semejante construcción, y tráfico a cualquiera otra persona, a quien por expressa ordenanza no le sea permitido o que no sea artífice platero con tienda abierta, ya sea de los que se ocupen generalmente en hacer toda especie de obras, o ya relicarios, y alhajas feligranadas, u otras iguales los que se arreglarán en su construcción a la ley señalada por ordenanza, baxo las penas establecidas a los contraventores, en las que asimismo incurrirán si en el preciso término de quince días no acuden a manifestar las citadas cruces, medallas, $\& c$ a fin de que verificado su intrínseco valor, se les entregue por cuenta de las platerías para fundirlas de nuevo, sin que le sirva de escusa de ser las cruces, o medallas tocadas a alguna Imagen, pues prescindiendo de la falacia, o engaño práctico, que frecuentemente se observa, el que quisiere tener esta devoción podrá usar de otros medios, que llenen su piedad, y no perjudiquen el regulado tráfico de las especies de oro, u plata en conocido daño de la causa pública. 
Capítulo IX. Se exceptúan de la prohibición las Iglesias, y comunidades, que acostumbran repartir cruces, y Medallas de devoción, siendo fabricadas de la ley prefinida.

Se exceptúan de la prohibición expressada las comunidades religiosas que acostumbran distribuir Imágenes; por ejemplo, la de Nieva, admitiendo las limosnas bajo el concepto de dedicarse para el culto Divino: pero estarán igualmente obligados los plateros que las fabricasen, o vendiesen, ya sean de oro, o ya de plata, a no hacerlas por si, ni para Iglesia, ni Comunidad alguna de menos ley que la prefinida a los metales baxo las penas que quedan impuestas; pues aunque cada medalla de por si parezca cosa leve, no lo es, atendida la multitud, y la gran massa que se distribuye en el Público; y para que se pueda esto averiguar 10 conveniente, será del cargo, y obligación de los tales Plateros entrtegar al secretario de la congregación al fin de cada año Certificación jurada de la porción de medallas que huviese vendido, o fabricado, expecificando su peso, la comunidad a quien las vendió, o por cuya cuenta las trabajó, y ser de las leyes prefinidas; y en caso de hallarse algunas medallas que no las tengan, y se averigue el Vendedor, o Fabricante, no sólo incurrirá en las penas establecidas, sino en la de cien ducados más, o por no haver dado la certificación, o por haver faltado en ella a la verdad.

\section{CONCEPCIÓN ALARCÓN ROMÁN}

Museo del Pueblo Español. Madrid

En este artículo se analiza la iconografía de Cristo, María y los santos, de un puñado de santuarios ubicados en diferentes regiones españolas, tal como se veía y reflejaba en el siglo XVIII. Estampas y medallas devocionales sirven para recrear un mundo que está entre la historia del arte y la etnografía, porque no sólo nos preocupa cómo son y de qué materiales están hechos estos objetos, sino que también vemos los privilegios de fabricación, su mercado y el uso que hacen de ellos los devotos. Enmarcado todo ello en la época de Carlos III, que legisló especialmente en materia de platería y grabado en los lugares sagrados.

This article analyses the iconography of Christ, Mary and the saints of some shrines situated in different Spanish regions as was seen and reflected in the eighteenth century. Through devotional engravings and medals we recreate a world between Art History and Ethnography, since wath we are interested in is not only their formal description, but also the privileges associated with their fabrication, their market and the use that the devout made of them. And all this within the context of the reign of Carlos III, when the silversmith's trade and religious prints were regulated. 

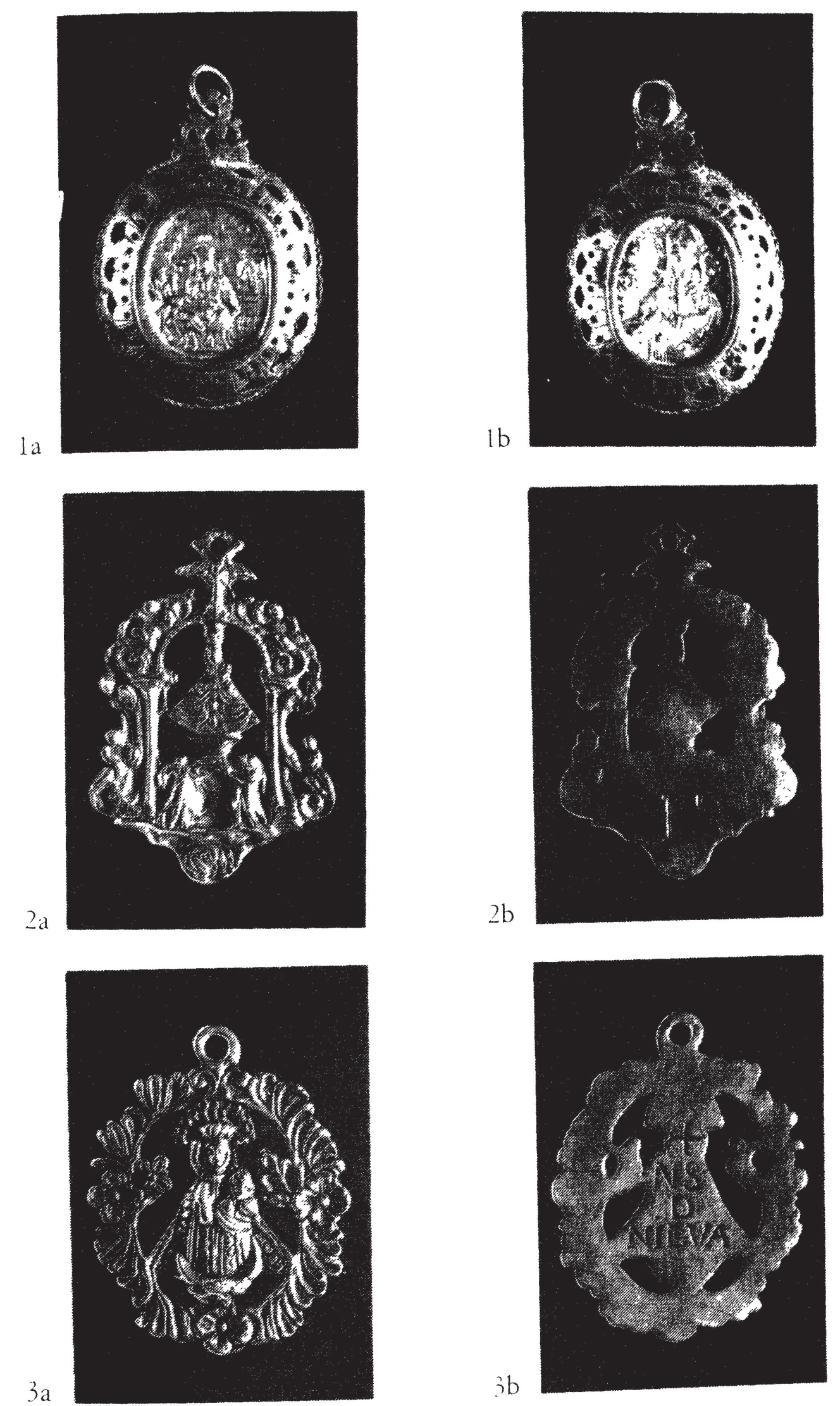

LÁM. I. Medallas la y b: Nuestra Señora de Montecrat I S. Benitos. Plata $7 \times 6 \mathrm{~cm}, \mathrm{MPL}$. n. inv. 12.531 - 2a y b: Nuestra Sra de Peña de Franci, Plata durada \& $\Varangle 5 / 3.4$ cms / MPl:.

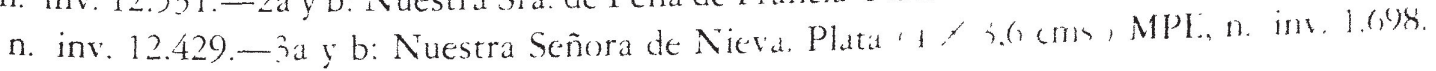



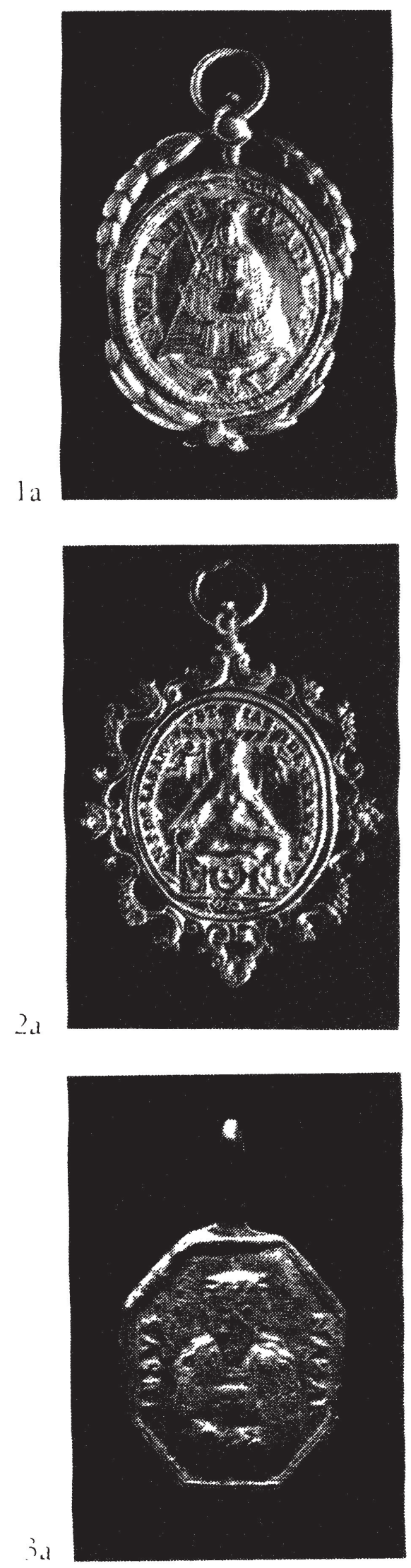
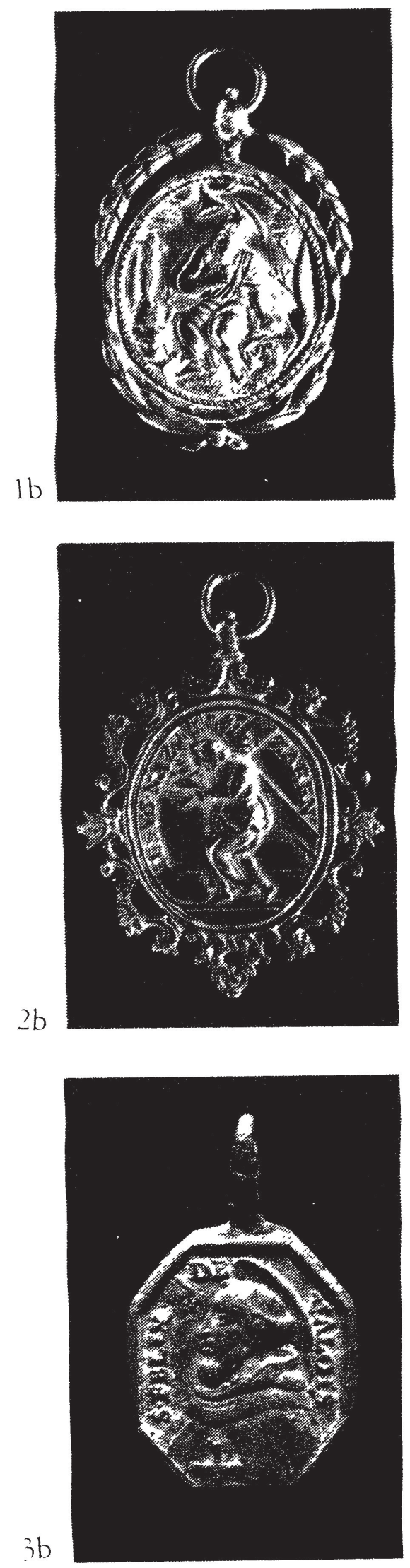

L.AM II. Medallas la y b: Nuestra Señora de Ciudalupe y Serónimo Metal dorado y plata $(+, 5 \times 3$ cms.) MPE. 11,79)(0,-2a y b: Nuestra Señora de las Angustias y Nazareno. Plata $15,1 \times 4,5 \mathrm{cms}, \mathrm{MPE}, \mathrm{n}$ in 12.521 - ia y b: Jesús Nazarneo y S. Félix de Valois. Bronce $3,3 \times 2 \mathrm{cms} .1$ MPE n. ins. $11.3+6$ 

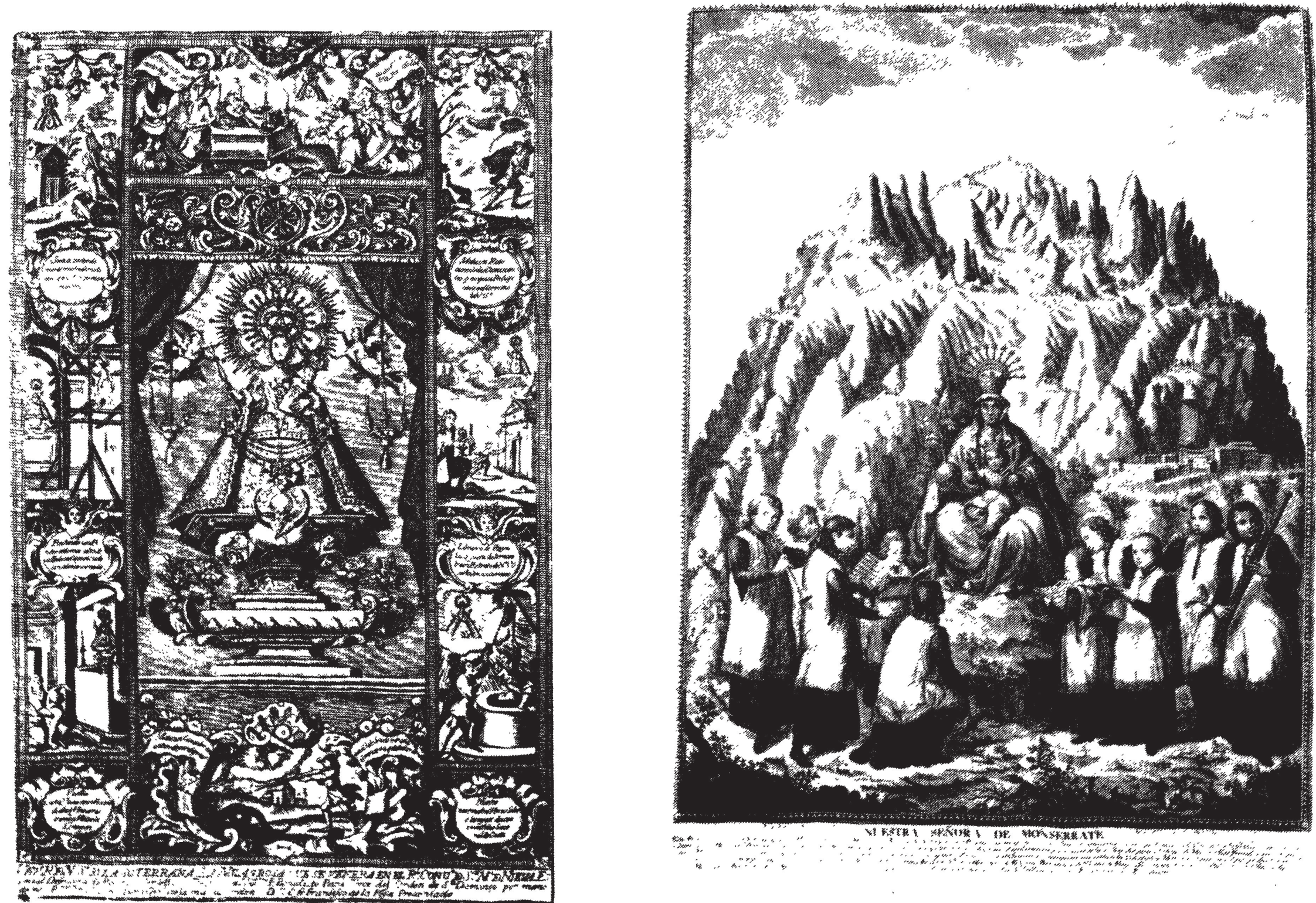

LAM. III. 1: Grabado de la Soterraña de Nieva. Antonio Espinosa de los Monteros, 1732. BN, n. inv. 13.789. 2: Nuestra Señora de Montserrat. Agustín Sellent, grab. y Joseph Flauger, dib. 1791. BN, n. inv. 36.119. 

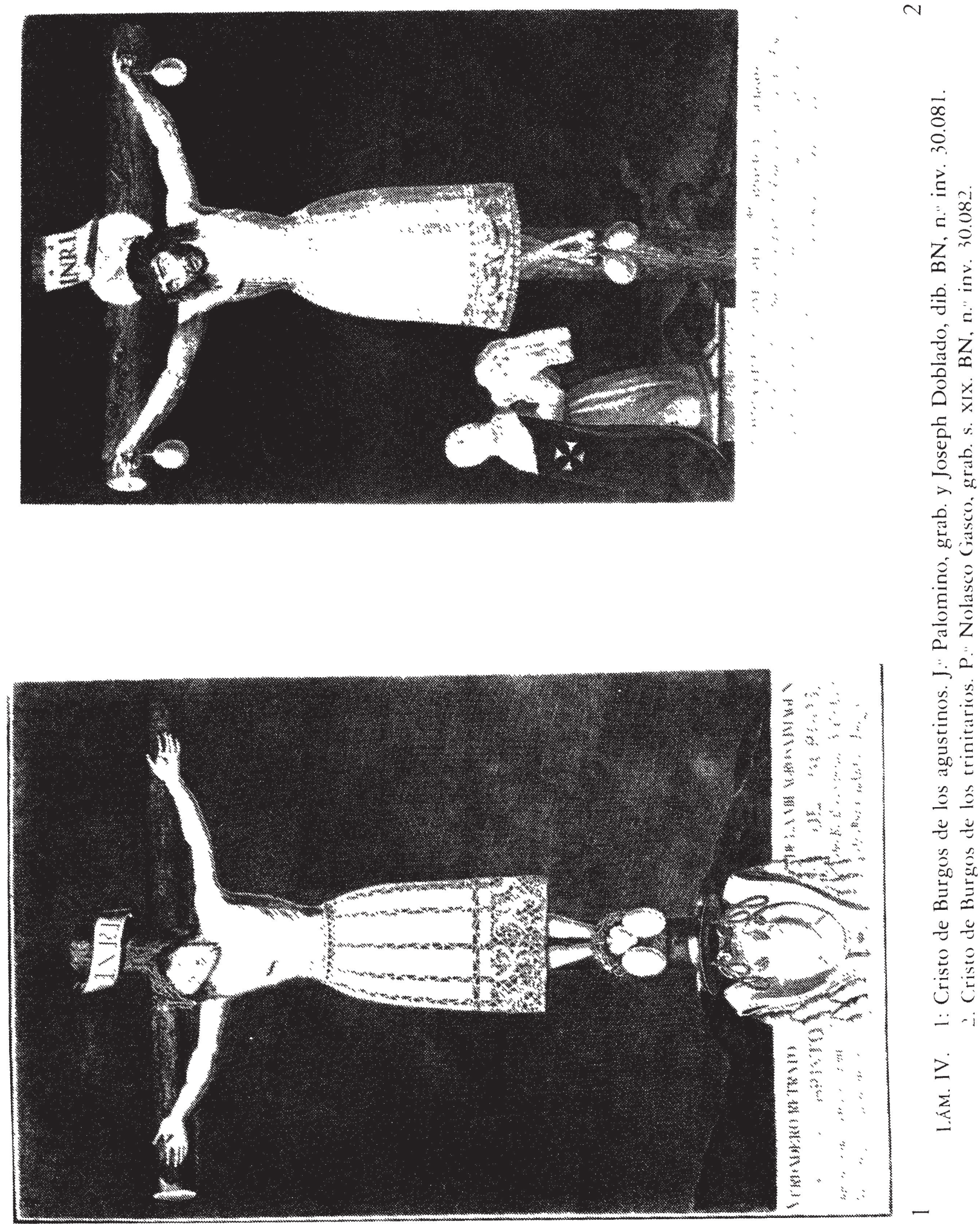


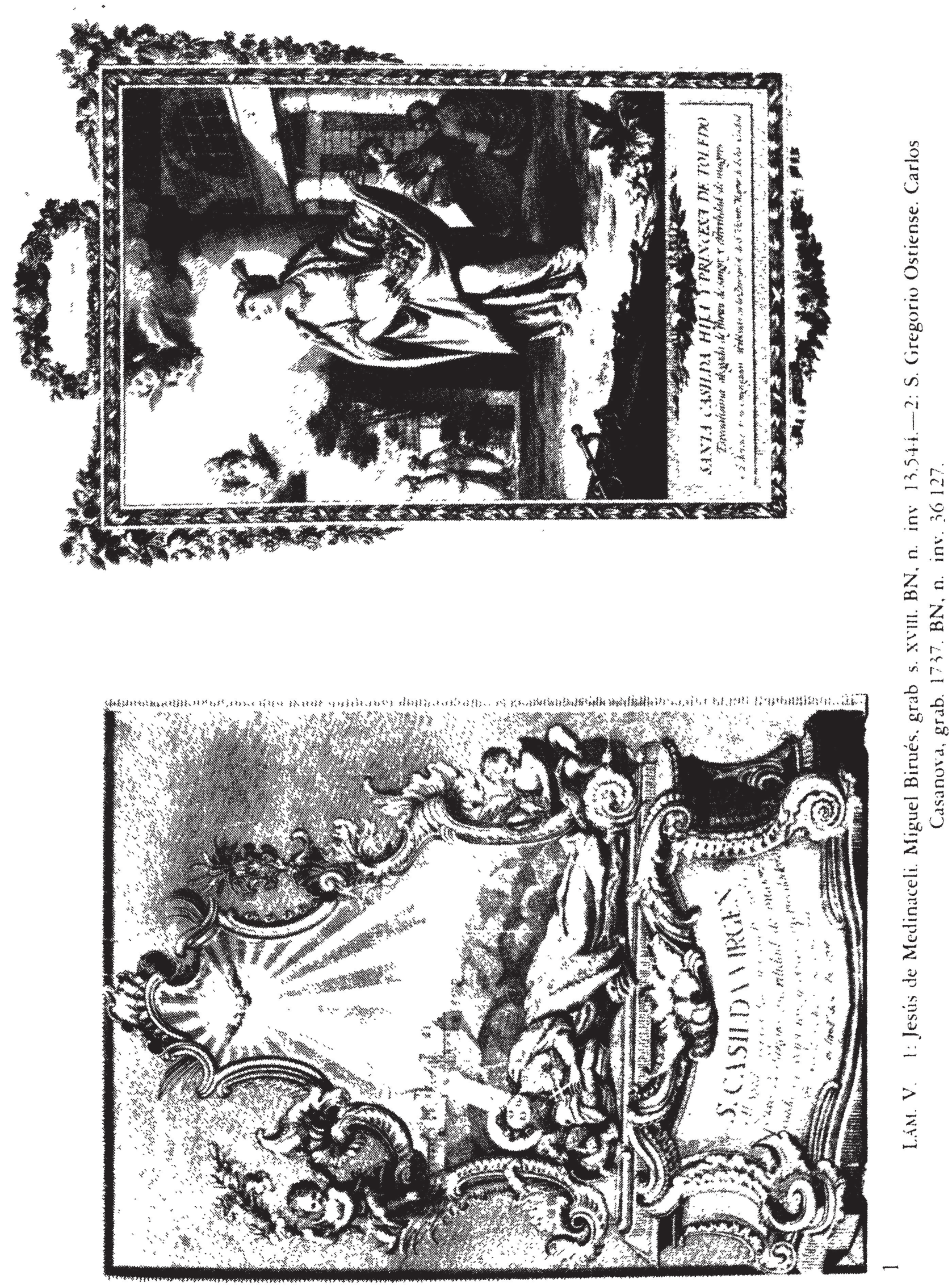



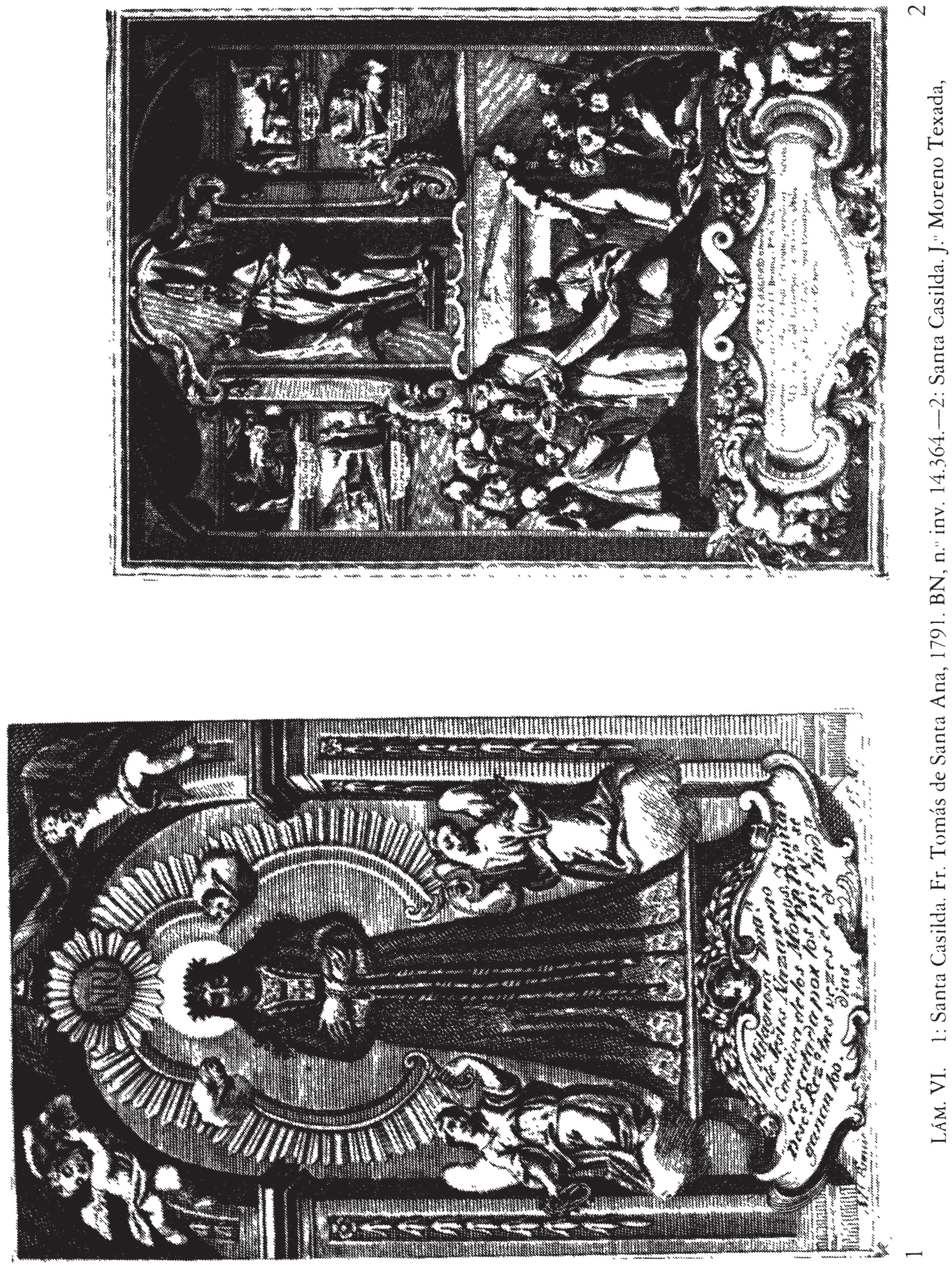